\section{Insuring against AIDS}

\section{AIDS is a problem for insurance companies, but} there are more awkward ethical problems.

THE chief demographic consequence of the epidemic of AIDS (acquired immune deficiency syndrome) is to reverse the tendency in recent years towards declining mortality among those in middle life. That is why, at least in industrialized countries, this novel cause of death has already begun to touch even the uninfected - in their pockets. So much is clear from the response of the life-insurance industry to the spread of AIDS. A document now published by the British Institute of Actuaries shows how the wind is blowing. Even in Britain, where the prevalence of infection by the AIDS virus (HIV) is much less than in, say, the United States, the actuarial calculations of the insurance companies have taken a sombre turn. The 100,000 deaths from AIDS expected by the end of the century (but there may be several times as many) are comparable with the number ordinarily expected among the insured population. The result is that life insurance will cost more.

Life insurance is a distinctively capitalist device by which people seek to avoid the consequences of untimely and unexpected death. The principle is that people in similar circumstances should while alive contribute part of their income into a common pool, with the understanding that the funds accumulated, together with interest (and such profits as accrue on the world's stock markets), are used to compensate the dependants of those among them who die unexpectedly. There is an implied contract binding the members of an insured group that they will not recklessly hazard their lives; professional motor-car racers must pay extra (or be insured separately), as (nowadays) must those who smoke cigarettes. The life-insurance companies administering these schemes are not usually popular; although they are usually tightly regulated to ensure that they do not squander their members' savings, they are frequently accused of making profits at the expense of people's sense of insecurity and of operating over-stringent rules for deciding eligibility for insurance. But few would deny them a place in the modern world.

The arrival of AIDS is bound to upset the insurance companies' applecarts, not least because it is inevitable that many of those already belonging to insurance schemes are, or will be, infected with HIV. Using a model of the AIDS epidemic which is necessarily uncertain, but which cheerfully makes no allowance for the spread of AIDS to, and subsequently from, women, the Institute of Actuaries calculates that mortality among British males aged between 30 and 40 will be at least doubled, and perhaps multiplied by three or four, in the decade ahead. This result emerges from the conservative assumptions that the proportion of the population at risk of infection (chiefly from male homosexuality and intravenous drug abuse) does not exceed 2.5 per cent of the total of males betwen 20 and 50 years. The financial consequences are potentially serious for insurers and their customers; the true actuarial cost of life insurance may be two or three times what it has been in the past, perhaps more.

None of this is surprising, nor can people complain if insurance companies seek to insulate themselves from future risks by denying insurance to those at risk of AIDS infection. That is why the companies have been edging towards proposals forms carrying questions about sexual proclivities that would previously have seemed impertinent. Blood-tests are also being required for larger contracts. One practical difficulty is that blood-tests cannot spot AIDS infection during the latency period, the duration of which may be long and variable, between infection and the appearance of antibodies. By the same test, the insurance companies cannot hope to tell in advance who will be infected by HIV through blood transfusions.

More serious ethical questions follow. Those applying for life insurance cannot tell at the outset of what is literally a life-long contract, whether their circumstances will change. What, for example, is to happen to a person who honestly declares himself not to be a male homosexual, but who in later life finds himself drifting into homosexual practices? Under present law, the question having been asked, the insurance company could declare the insurance contract null and void, thus declining to pay insurance benefits to a large proportion of those on their books who eventually die of AIDS. On the face of things, that may seem a just defence of the interests of other policy-holders, but it may nevertheless be thoroughly inequitable. The crucial question is whether the emergence of homosexual tendencies, or even of drug dependence, is to be regarded as a voluntary or an involuntary development. It will take others than actuaries to tell where the truth lies.

\section{Farming trade wars}

\section{Japan should be more forthcoming in its dispute with the United States over farm products.}

JAPAN, constantly in hot water with the United States over the frequently ill-founded suggestions that it unfairly skews the balance of trade in its favour by protectionist devices, is behaving tactlessly in the latest squabble - the US demand that trade in agricultural products should be liberalized. The issue has dragged on for years, but came to a head last year when the United States won a ruling from the General Agreement on Tariffs and Trade (GATT) that Japan should liberalize its trade in a dozen different agricultural products, from oranges and milk powder to beef.

The essence of the dispute is that the US government believes that US producers, if on the wrong side of the consumer electronics war, might at least make a better showing with beef and citrus fruit, which is a certainty. The prices of most farm products in Japan are held at levels much higher than world prices - that of rice, for example, is roughly three times the market price. The US case against Japan is nevertheless muted by the common knowledge that the United States is not against farm subsidies as such, and that it differs from most other governments only in the generosity of its support for farmers. The reasons why Japan featherbeds its farmers are largly political, but by ensuring that taxpayers pay above the odds for food, the government has at least found a convenient way of enabling farmers to share in the general prosperity that has come to Japan. That is more respectable than most arguments in favour of agricultural subsidies. In a world in which nobody's hands are clean on agricultural subsidies, Japan is likely to get away with its intended offer at next month's Washington negotiations the proposal to increase import quotas yet again.

Unfortunately, quotas are not a substitute for free trade, but a poor and partial imitation of it. The immediate beneficiaries of increased quotas are likely to be cattlemen in Texas and orange growers in California, but the beneficiaries of open agriculture would probably be a different lot of people altogether - in the short run, Australian cattlemen, further ahead, closer neighbours of Japan with ambitions to move faster in all-round development. South Korea may already have gone too far down the Japanese road, but there is always China and the rest of Asia.

The Japanese and US governments are not alone in being hostage to their farmers, and to their farmers' votes. Most other governments are also bedevilled by them. But, so far, only the United States has taken an honourable stand by demanding that farm subsidies should be abolished within the framework of the next round of GATT negotiations. What stands out from the Japanese response to US complaints over beef and oranges is that Japan, for one, does not believe that will happen. So much is implicit in the intended offer of larger quotas, not liberalization (which is not inconsistent with import tariffs). That is tactless of a government often pilloried, sometimes wrongly, for seeking to shield its people from competition of the kind by which it has itself prospered. 